\title{
インタネットで個人放送局を開くには(2)
}

\author{
正会員 甲 藤 二 郎 ${ }^{\dagger}$
}

インタネット上で個人放送局を開設するための技術解説を行う。第 2 回はストリーミング技術の後半と, 具体的なソフトウェアの実装方法について説明する。次回（最終回）は，代表的なストリーミングソフト ウェアの使用方法について説明する。

キーワード：インタネット放送，プレゼンテーション記述，ユニキャストとマルチキャスト，ストリーム・キャッシング， マルチメディア・プログラミング，ネットワーク・プログラミング

\section{6 プレゼンテーション記述}

インタラクティブテレビに代表されるように，テレビ番 組にWebに似たインタフェースをかぶせることで，インタ ネット放送のコンテント面の拡張を実現できる。このため に使用されるのがプレゼンテーション記述言語である。さ まざまなフォーマットが提案されているが（D-HTML， MHEG，MPEG-4等)，本稿ではその代表例としてW3C (World Wide Web Consortium) で標準化されたSMIL (Synchronized Multimedia Integration Language) について説 明を行う1)。

SMILはXMLに準拠しており，HTMLに慣れた者なら誰も が容易に習得できる。図1に示すように，プレゼンテーシ ヨン記述をレイアウト記述と同期記述に分類し，前者はメ ディアの空間的な配置を, 後者はメディアの時間的な関係 を記述する。

具体的には，レイアウト記述は <layout $>\ldots<$ layout $>$ の夕 グで囲まれる，同期記述は < par > ...</par>，あるいは<seq $>$ ...</seq $>$ の夕グで囲まれる. 同期記述の $<$ par $>$ と <seq $>$ は, それぞれ並列再生と逐次再生を表す。四1（b）との対応で 言えば，<par>を用いてビデオとオーデイオの並列関係を 記述し，<seq>を用いて二つのビデオの順番を記述する。 なお，詳細は文献 1）を参考にされたい.

プレゼンテーション記述に個々のストリーム情報（SDP 等）を含めた構成も考えられるが，一般的に両者は分離さ れる。具体的な配信は，

・プレゼンテーション記述（SMIL等）

・個々のストリーム情報（SDP等）

・ストリーミング開始（RTP等）

の手順で行われる。リアルプレイヤやMPEG-4のように，

†早稲田大学 理工学部電子・情報通信学科

"How to Open Personal Broadcasting System on the Internet (2)" by Jiro Katto (Department of Electronics, Information and Communication Engineering, School of Science and Engineering, WASEDA University, Tokyo)

$622(34)$

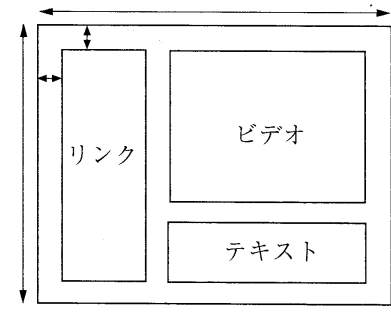

(a) レイアウト記述

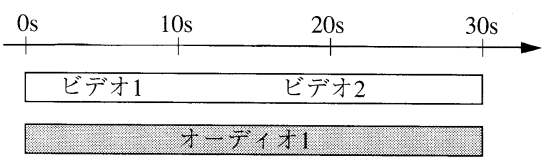

(b) 同期記述 $\langle$ smil $\rangle$ $\langle$ head $>$ レイアウト記述

$\langle/$ head $\rangle$ $\langle$ body $\rangle$ 同期記述 $\langle/$ body $\rangle$ $\langle/ \mathrm{html}\rangle$

(c) SMIL 記述の構成
図 1 SMILによるプレゼンテーション記述

セッション中に動的にプレゼンテーション記述を更新でき るものもある。これらはテキストやグラフィックスのスト リーム転送もサポートしている。

なお，プレゼンテーション記述は各ストリームの時間関 係を指定しているだけで，決してそれ自体がメディア同期 を実現するものではない．前回説明を行ったように，あく までもメディア同期は別のレイヤ（RTP等）で扱われるも のである.

2.7 ユニキャスト，マルチキャスト，スプリッタ

インタネット放送の放送形態として，図2に示す3方式が 考えられている ${ }^{2) 3}$.

$$
\begin{aligned}
& \text { ·ユニキャスト } \\
& \text { ·マルチキャスト } \\
& \text { ・スプリッタ }
\end{aligned}
$$

ユニキャストはサーバとホスト（受信端末）を1対1に接続 する方式で，インタネットで通常用いられる接続形態にほ かならない.よって，現在のインタネット放送は，ほとん どがユニキャスト方式で運用されている.

しかし，ユニキャストではホスト数分だけコネクション 


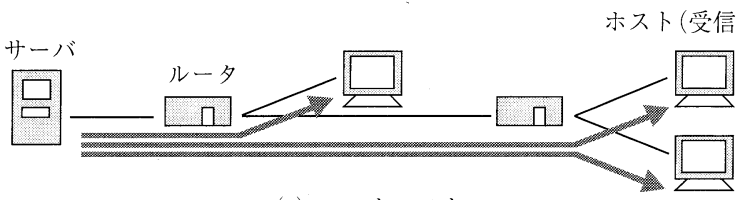

(a) ユニキャスト

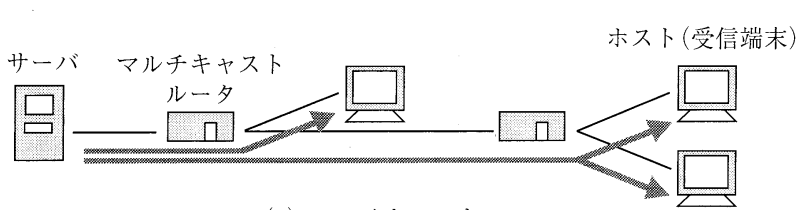

(b) マルチキャスト

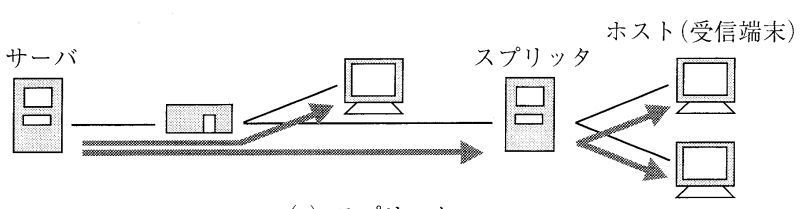

(c) スプリッタ

図2インタネット放送の配信形態の分類

を張らなければならない。このため，ホスト数の増加と共 にサーバの負荷が増大し，さらにはネットワーク全体のト ラヒックが爆発する危険性もある。これを解決するために， マルチキャスト方式とスプリッタ方式が提案されている。

マルチキャストでは，クラスDの特殊なIPアドレス （224.0.0.0〜239.255.255.255）を使用し，IPアドレスとポー 卜番号によって決まるグループ（マルチキャストグループ） に属するホストだけにパケットを配信する。このとき，サ 一バから送出されるパケットは一つだけであり，途中のル ータが特定の経路（マルチキャストッリー）に向けてパケ ットをコピーしながら転送する。このため，サーバがホス ト毎にコネクションを張る必要はなく，トラヒックの増加 も必要最小限に抑えられる。

マルチキャストのために使用されるのが，IGMPと各種 のマルチキャスト経路制御プロトコルである．IGMPは， ホストのマルチキャストグループへの参加や離脱を通知す る。また，経路制御プロトコルは，IGMPに応じて動的に マルチキャストッリーを決定する。具体的には，IGMPを 用いてホストが参加要求を行うと，マルチキャストッリー が延長されてパケット転送が開始される。逆にホストが離 脱すると，マルチキャストッリーが切り取られて転送が停 止する。代表的な経路制御プロトコルとしては, DVMRP, MOSPF，PIMなどが知られている。

ライブ放送や時間指定を行うオンデマンドサービスにと って，マルチキャストの有効性は明らかである。また，最 近出荷されている大部分のルータやOSはマルチキャストに 対応して抢り，インフラの準備も整っている。しかしなが ら, 設定の手間や運用面の不安感のため, 現在もMboneや Internet 2を介した評価実験が進められている ${ }^{4}$.

これに対してスプリッタ方式は，マルチキャストのよう

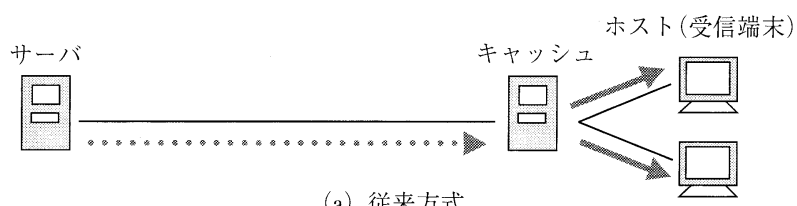

(a) 従来方式

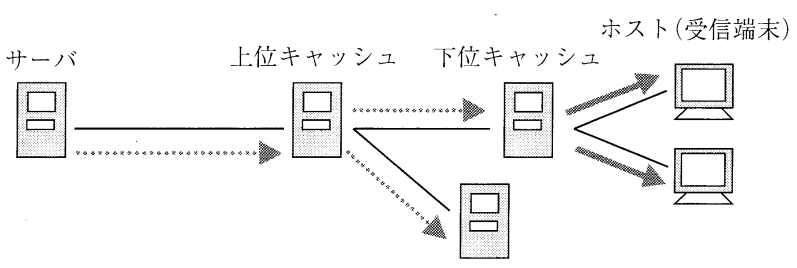

（b）階層化・分散キャッシュ

図３ストリームキャッシングの分類

な大きな変更を伴わず，前述の問題を緩和する方式である． サーバとホストの間にスプリッタを配し，サーバからスプ リッ夕までは1本のユニキャストで，スプリッタからホス 卜までは複数本（ホスト数分）のユニキャストでパケット を転送する。このため，スプリッタの適切な配置を行うこ とで，ネットワークのトラヒック（特にバックボーントラ ヒック）を大幅に削減することができる。さらには，オン デマンド用途でスプリッタをミラーサーバとして運用すれ ば，後述するキャッシュサーバとしてパケット転送遅延の 削減にも有効に機能する。

2.8 ストリームキャッシング

オンデマンド用途で，スプリッタをミラーサーバとして 運用し，さらにインテリジェントなキャッシュサーバとし て運用することにより，ネットワーク全体のトラヒックと パケット転送時間を削減できる。これは通常のWebキャッ シングと同様の効果である ${ }^{5) 6}$.

ただし，ストリームデータのサイズは非常に大きい場合 があり，すべてをキャッシュするには限界がある。また， ストリームデー夕特有の性質として, 時間的に先行するデ 一夕は頻繁にアクセスされるが，後半のデータのアクセス 頻度は下がるいう傾向がある。よって, プリフェッチも可 能で，ストリームデー夕に適したキャッシングを行うこと で，パフォーマンスをさらに向上できることが期待される。

筆者らは

・キャッシュサーバの階層化と分散配置

・ストリームデータのセグメント分割

・セグメント単位のキャッシュ管理

・Webキャッシングとの親和性 を骨子とするストリームデータのキャッシュ方式に関する 検討を進めている778). 図3には，ストリーム・キャッシュ 方式の分類を示す。比較実験の結果として, 階層化・分散 キャッシュ方式によって，Webキャッシングの効率を下げ ることなく, トラヒック量, キャッシュヒット率（転送遅 延）共に改善できることを明らかにしている。 


\begin{tabular}{|c|c|c|c|}
\hline ビデオ & オーデイオ & SDP & $\begin{array}{c}\text { プレゼンテーション } \\
\text { 記述 }\end{array}$ \\
\hline RTP/RTCP & RTSP, SIP, SAP* & HTTP 等 \\
\hline UDP or TCP & TCP \\
\hline \multicolumn{2}{|c|}{} \\
\hline \multicolumn{2}{|c|}{} \\
\hline
\end{tabular}

*SAPはUDPによるマルチキャスト転送

図４インタネット放送の典型的なプロトコル階層

\section{9 総括}

2.2節から 2.6 節までの説明をまとめると，インタネット 放送の典型的なプロトコル階層は図4のようになる。これ らの実装によって，ストリーミングソフトウェアが完成す る。さらに，2.7節と2.8節で説明したスプリッタやキャッ シュサーバの配置により，トラヒックや転送遅延を削減す ることができる。

表1は，インタネット放送で使われる代表的なソフトウ エアの一覧を示している。世界的に広く使用されているの
は，リアルネットワークス社，マイクロソフト社，アップ ル社の3製品である．数年前はより多くの企業が参入して いたが，数多くの買収・合併を繰り返して現在に至ってい る．例として，Waveletとスケーラブル符号化のVDONet社， VxTreme社, HTTPストリーミングのVivo社, MPEG-1スト リーミングのXing社，などが挙げられる。

図4の構成に最も忠実なのが，リアルネットワークス社 の製品群である。これは各種制御プロトコルやSMILの策 定に直接関わっていたことが背景にある。同様に，アップ ル社の製品群も国際標準に忠実な実装を進めている。一方, マイクロソフト社の製品群は必ずしも国際標準に準拠して いない。これは逆にオペレーティングシステムを含めたデ ファクト化を行える強みではあるが，ブラックボックスが 増えることは気持ちが悪い一面もある.

表2と表3は，各種標準化文書と対応する参照ソフトウェ アの入手先を示す．SMILを除き，参照ソフトウェアはす ベて C/C++のソースコードを含む。ただし，SMILに関して も，SGML/XMLパーサのソースコードが各種公開されてい る (http://www.oasis-open.org/cover/ 等)．筆者自身はSMIL パーサを作成したことはないが，これらを拡張することで 対応可能であると思われる。

表 1 インタネット放送の商用ソフトウェア

\begin{tabular}{c|c|l}
\hline 組織名 & システム名称 & \multicolumn{1}{c}{ URL } \\
\hline \hline リアルネットワークス & RealSystem & http://www.real.com \\
\hline マソイクロソフト & Windows Media & http://www.microsoft.com/windows/windowsmedia \\
\hline アップル & QuickTime & http://www.apple.com/quicktime \\
\hline シスコシステムズ & IP/TV & http://www.cisco.com/warp/public/cc/pd/mxsv/ \\
\hline NTT & SoftwareVision & http://www.softwarevision.or.jp/ \\
\hline KDDI & QualityMotion & http://w3-mcgav.kddlabs.co.jp/qm/ \\
\hline 東芝 & MobileMotion & http://www2.toshiba.co.mmotion/ \\
\hline キャノン & WebView & http://www.x-zone.canon.co.jp/WebView/
\end{tabular}

表 2 プロトコル文書の入手法

\begin{tabular}{|c|c|c|}
\hline 組織名 & プロトコル、標準名 & URL \\
\hline \multirow[t]{2}{*}{ IETF } & $\begin{array}{c}\mathrm{RTP} / \mathrm{RTCP} \\
\text { ペイロードフォーマット }\end{array}$ & http://www.ietf.org/html.charters/avt-charter.html \\
\hline & SDP,TRSP,SIP,SAP & http://www.ietf.org/html.charters/mmusic-charter.html \\
\hline ITU-T & H.323,H.26X & http://standards.pictel.com/ \\
\hline ISO/IEC & MPEG & http://www.cselt.it/mpeg/ \\
\hline W3C & SMIL & http://www.w3.org/AudioVideo/ \\
\hline
\end{tabular}

表 3 参照ソフトウェア（SMILはバイナリーのみ）

\begin{tabular}{c|c|l}
\hline 組織名 & \multicolumn{1}{|c}{ プロトコル } & \multicolumn{1}{c}{ URL } \\
\hline \hline UCB,UCL & RTP,SDP,SIP,SAP & http://www-mice.cs.ucl.ac.uk/multimedia/software/ \\
\hline コロンビア大他 & RTSP & http://www.cs.columbia.edu/hgs/rtsp/implementations.html \\
\hline オープンプロジェクト & H.323 & http://www.openh323.org \\
\hline \hline リアルネットワークス他 & SMIL & http://smw.internet.com/smil/smilhome.html \\
\hline
\end{tabular}




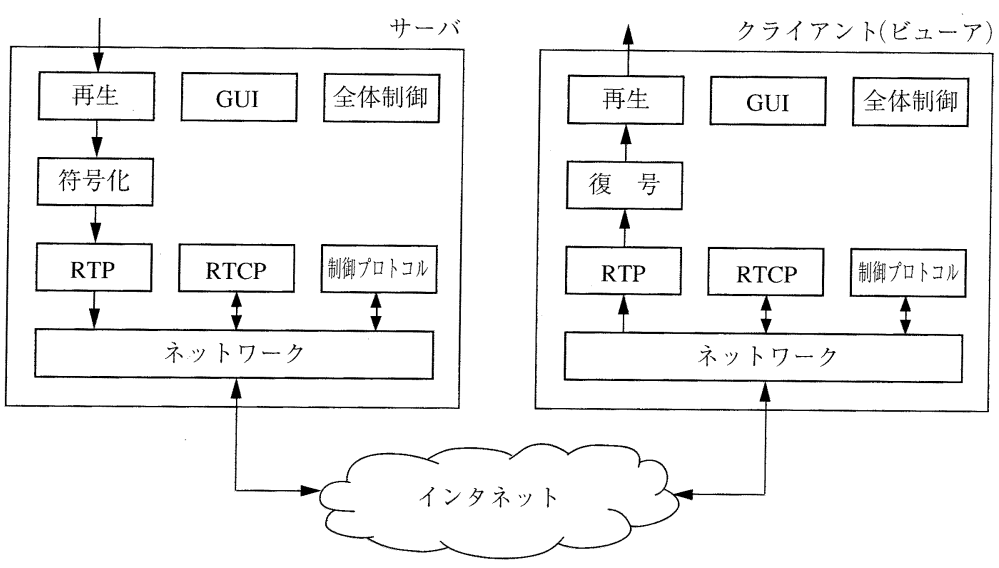

図 5 ストリーミングソフトウェアの構成例

\section{3. ストリーミングソフトウェアの作成}

\section{1 概要}

リアルプレイヤやメディアプレイヤを短期間に作成する ことは難しいが，プロトタイプであれば考えるほど難しい プログラミングではない. 特に, 大学院生等にとっては実 践的な演習課題にもなる。そこで本章では，簡単なストリ ーミングソフトウェアの作成方法について説明する.

図5に，ストリーミングソフトウェアの構成例を示す。 図4のプロトコルスタックに加えて，AVデータのキャプチ ヤと再生, GUI (Graphical User Interface), 周辺要素として のマルチスレッド，タイマイベントなどの実装が加わる. なお，以下ではライブ放送を前提とする。これは，オンデ マンドサービス（VOD）は，制御プロトコルを除いてライ ブ放送のサブセットとして実現できるからである。また， 制御系ではプレゼンテーション記述と制御プロトコルは扱 わず，RTP/RTCPのみ説明する。これは，RTP/RTCPがスト リーミングに必須の要素を含むからである。使用言語は $\mathrm{C} / \mathrm{C}++$ ，オペレーティングシステムはWindowsとLinuxを対 象とする。また，サンプルプログラムは紙面では割愛し， 筆者のWebページに掲載する ${ }^{9)}$.

\section{2 要素技術}

(1) マルチスレッド

ひとつのプログラムを実行し，その中で複数のモジュー ル（スレッド）を並列動作させるために使用する。サーバ 側のキャプチャ，符号化，送信，ビューア側の受信，復号， 再生などは，マルチスレッド化することが望ましい.

ただし，マルチスレッドでは各モジュール間のデータの 受渡しに競合が発生する（データの読出しと書込みが同時 に発生する)。これを回避するために，モジュール間にバ ッファを設け，mutex等の排他制御を用いてバッファアク セスを行う必要がある。

(2) タイマイベント

特定の処理を，時刻を指定して実行する場合に使用する。
ビューアにおける同期再生のための復号処理，定期的な RTCPパケットの送信，などに有効である．Windowsの場合 はマルチメディアタイマ，Linuxの場合は後述するGUIツー ルキットが提供するタイマ関数が使いやすい.

(3) GUI (Graphical User Interface)

アプリケーションのGUIインタフェースを提供するため に使われるのが一連のGUIツールキットである。Windows の場合はWin32とMFC，Linuxの場合はGTK，Qt，Tcl/Tkな どが代表例である。

GUIプログラムは一般的にイベント駆動構成となる。す なわち，プログラムを起動して無限ループに入るメイン関 数と, 発生したイベントを処理するイベント処理部から構 成される。このとき, メイン関数の無限ループはイベント 待ちループにほかならない。

\section{3 マルチメディアプログラミング}

ビデオ，オーディオ信号のキャプチャと再生はOSに依存 する部分が多く，必然的にOS依存のプログラムを書き分け なければならない。これに対して符号化，復号はOSに依存 する部分が少なく，好対照をなしている.

また，通常のファイル形式によるキャプチャ，再生とは 異なり，ストリーミング用のAPI (Application Program Interface）はほとんど提供されていない。このため，より 低レベルのプログラミングが必要になる。この点が，ダウ ンロード（ファイル形式）とストリーミングの大きな違い でもある。

（1）キャプチャと再生

ビデオキャプチャAPIでは，WindowsではVideo for WindowsやDirectShow，LinuxではVideo4Linux等が使用され る。オーディオキャプチャAPIでは, WindowsではMCI (Media Control Interface) やDirectSound, LinuxではOSS （Open Sound System）等が使用される. ビデオ再生APIでは, Windows，Linux共にGUIツールキットが利用でき，あるい はWindowsの場合はDirectDrawも用いられる。オーディオ 再生APIでは，WindowsではMCIやDirectSound, Linuxでは 
OSS等が使用される.

マルチスレッドで述べたように，キャプチャと符号化部， 復号と再生部のデータの受渡しには注意が必要である。特 にオーディオの場合, キャプチャバッファからの読出し, 再生バッファへの書込み時に, 現在のキャプチャ書込み位 置, 再生読出し位置を超えてアクセスを行わないようにす るなど，充分な制御を加える必要がある。

(2) 符号化と復号

符号化と復号は，オペレーティングシステムの違いを意 識することなく, C/C++の標準的な関数を用いて実装する ことができる，無論, MMX等のアセンブラ命令を組み込 む場合はOS（およびCPU）依存となる、筆者自身の経験は 充分とは言えないが，世界初のソフトウェアデコーダであ るMPEGplay以来有効な高速化手法はテーブル参照である. 以前は有効とされた整数演算と浮動小数点演算の時間差 は, 最近のStreaming SIMDや3D now!の登場によって顕著 ではなくなってきている。一方, Web上に存在する参照ソ ースはファイル対応のものが多い.これをストリーミング 対応に修正するためには，すべてのファイル $\mathrm{I} / \mathrm{O}$ 記述を取り 除き，ネットワークアプリケーションに適したインタフェ 一スとなるように関数を再定義すると使いやすい.

3.4 ネットワークプログラミング

TCP/IPの処理モジュールはカーネルに組込まれており， 通常はソケットと呼ばれる抽象化されたインタフェースを 介してパケットを送受信する ${ }^{10)}$.もちろん，Linuxのように ソースコードが公開されている場合は, 必要に応じてカー ネル部分をカスタマイズしても構わない.

(1) ソケットプログラミング

ソケットとはTCP/IPプロトコルを実行するための抽象化 されたインタフェースのことである。これを使うことで TCP/IPの詳細を記述する必要がなくなり，プログラムの作 成が簡略化される。

基本的な使い方としては，はじめにTCP，UDPのいずれ かを指定したソケット（ソケット識別子）を作成する。こ れとIPアドレスとポート番号を指定したSockaddr構造体を 結び付け，一連のソケット関数を実行する。簡潔に言えば， ソケットを介して送受信端末を結合し，TCP/IPによるデー 夕転送を実行する。インタネット放送の場合は，メディア チャネル毎，制御チャネル毎，すなわちポート毎に複数の ソケットを作成する必要がある。必然的にマルチスレッド 化が求められる.

(2) マルチキャスト

マルチキャストに対応するためには，ネットワーク部の 修正が必要である。ただし，追加量はわずかであり，サー バ側，クライアント共にip_mreq構造体と若干のオプション の追加によってマルチキャスト化は完了する。これはソケ ットの恩恵に他ならない.これによって，アプリケーショ ン実行時にIGMPが実行されることになる。
むしろ厄介なのはマルチキャストサーバの設定である. ストリーミングソフトウェアをマルチキャスト対応にした ところで, 所属するドメインのルータがマルチキャストル ータでなければ，単にローカルにブロードキャストしてい るに過ぎない。このため，まずは管理者間で連絡を取り合 い，外部のマルチキャスト接続先を決定する必要がある. これはイントラネットかもしれないし，あるいはmbone等 の実験ネットワークかもしれない。その上で設定ファイル を用意し，ルータのマルチキャスト機能を有効にする（す なわち，IGMPパケットを送受し，マルチキャスト経路制 御プロトコルが動作するようにする)。これによって，初 めてマルチキャスト放送が可能になる。

\subsection{RTP/RTCP}

最後にRTP/RTCPについて説明する。ネットワークと順 番が前後するが，符号化・復号部とネットワークの間に位 置するモジュールである，基本的にRTP，RTCPそれぞれの 構造体を定義し，必要なパラメー夕を設定した上でパケッ 卜送受信を繰り返す。一連の同期再生, 誤り制御, フロー 制御に活用する。

(1) RTP

サーバ側の例として，ビデオ1フレーム分の圧縮データ から複数個のRTPパケットを構成する場合を考える。この 場合，例えば以下の処理を実行する。

・圧縮データの分割

・RTPパケットの作成

圧縮データの分割はパケット廃棄対策を兼ねる。つまり, RTPパケット毎に復号可能とするために，再同期位置に合 わせてパケットを分割する。最近は圧縮側で再同期をサポ ートする傾向にあり（MPEG-4, H.263+ 等), 圧縮デー夕 中のユニークワード探索によって分割位置を決定できる. あるいは，圧縮側で再同期データが揃うたびにRTPモジュ ールを呼び出す構成にしてもよい。そして，タイムスタン プ, シーケンスナンバ，フレーム区切り（M-bit）等を設定 し，分割データに添付してRTPパケットを構成する。

クライアント側では，パケット受信のたびに以下の処理 を実行する。

・RTPヘッダのチェック

・圧縮データの復元

・復号実行時刻の決定

まずシーケンスナンバのチェックを行い，番号が不連続 な場合は廃棄とみなし, 再同期情報に従って圧縮デー夕を 復元する。このとき, 復号部との整合を図り，復元データ を復号器がそのままデコードできるようにしておくと楽で ある。

よくインタネットではパケットの到着順序が逆転すると 言われるが, 経路制御は概してスタティックであり，順序 逆転はほとんど発生しない。 また，順序の逆転が起きた場 合には，パケットは再生時間に間に合わないことが多い。 
表 4 オペレーティングシステムと各種のAPIの例

\begin{tabular}{c|c|c}
\hline 目 & Windows & Linux \\
\hline \hline マルチスレッド & Win32, MFC & pthread \\
\hline GUI & Win32, MFC & X11, GTK, QT, Tcl/Tk, ... \\
\hline ビデオキャプチャ & Video for Windows, DirectShow & Video 4 Linux \\
\hline オーディオキャプチャ & MCI, DirectSound & Open Sound System \\
\hline ビデオ再生 & Win32, MFC, DirectDraw & X11, GTK, QT, Tcl/Tk, ... \\
\hline オーディオ再生 & MCI, DirectSound & Open Sound System \\
\hline ネットワーク & & ソケット
\end{tabular}

よって，インタネット放送のようなリアルタイム系アプリ ケーションでは, 順序逆転を廃棄とみなしてもあまり深刻 な問題にはならないことが多い.

またタイムスタンプやM-bitをチェックし，タイマイベン 卜等を用いて該当フレームの復号実行時刻を決定する。特 に，タイムスタンプ時刻から実際に復号を開始するまでの 時間はプレイアウト遅延と呼ばれ，ストリーミングソフト ウェアの即時性の尺度になる。つまり，一度設定すると， 同期再生のために同じ值に保たなければならず，プレイア ウト遅延を超えて到着したパケットは廃棄するしかない. よって, 即時性と廃棄率のトレードオフを考慮し, 適切な プレイアウト遅延を決定するメカニズムが重要である.

\section{(2) RTCP}

RTCPパケットは，例えばタイマイベントを使用し，送 受信端末間で定期的に交換する。これを用いた処理として 特に重要なのが, 同期再生用の時間軸の設定と輻輳制御の 実行である。なお，RTP/RTCPに使用するポート番号は対 であり，RTPに偶数 $2 \mathrm{~N}$ 番を用いた場合， RTCPには奇数 $2 \mathrm{~N}+1$ 番を使用する。

前回説明を行ったように,メディア内同期はRTPヘッダ のタイムスタンプで実現できるが，メディア間同期には RTCPパケットのNTP夕イムスタンプが必要である。この ため，セッション開始時にはメディア間同期が取れず， 個々のRTCPパケットが到着するまでは時間軸の対応付け ができない。これは現在のRTP/RTCPの制約上，やむをえ ないことである.

より重要なのが輻輳制御である，UDPストリーミングを 行う場合, 輻輳制御を行わないと他のTCPトラヒックのス ループットが低下する。これは，TCPが自身の輻輳制御メ カニズムによってレートを削減するためである。さらには UDPストリーム自身が網全体の輻輳を引き起こす危険性が ある。そこで，TCPとの公平性を保ちながら帯域を有効利 用するUDPの輻輳制御に関する検討が進められている。こ れはTCPフレンドリーと呼ばれ，代表例として

$$
T h=1.22 \cdot \frac{M T U}{R T T \cdot \sqrt{\text { loss }}}
$$

に従ってTCPと等価な転送レートを推定し、レート制御を 行う方式が知られている ${ }^{11)}$ 。このとき，Thは推定レート， MTUはリンクの最大パケットサイズ, RTTはラウンドトリ ップ遅延，lossはパケット廃棄率である。

商用ソフトウェアの輻輳制御としては, リアルネットワ ークス社のSure Streamやマイクロソフト社のインテリジェ ント・ストリーミングが有名である。共に技術的な詳細は 不明であるが，受信レートの測定に基づくフィードバック 制御，あるいは上記のTCPフレンドリの原理を用いている ものと推測される.

\section{6 総 括}

本章ではストリーミングソフトウェアの作成方法につい て説明を行った。まとめとして，表4ではプロトタイプ実 装に有用なAPIの一覧を示している，APIは日々変更される ものであり，陳腐化する危険性や，筆者の知らないAPIが あることも注意願いたい。

(2001年3月16日受付)

(第3回に続く)

\section{〔文 献〕}

1) W3C: "Synchronized Multimedia Integration Language (SMIL) 1.0 Specification”, http://www.w3.org/TR/REC-smil（Jun.1998）

2) 大澤光編著：“インタネットストリーミング”，共立出版 (2000)

3）苅田監訳：“マスタリングTCP/IP: IPマルチキャスト編”，オーム社 (1999)

4) K.C.Almeroth et al. : "The Evolution of Multicast: From the Mbone to Interdomain Multicast to Internet2 Deployment", IEEE Network (Jan.2000)

5）藤本訳：“Webサーバ完全技術解説”，日経BP社（1997）

6）インクトミ・ジャパン監修：“キャッシュ技術入門”, 小学館 (2000)

7）海老沢他：“マルチメディア・ストリームのための分散型キャッシン グに関する検討”, 2000信学会ソサイエティ大会, B-7-63（Sep.2000）

8）海老沢他：“Webキャッシングと親和性を持つストリーミング・キャ ッシング方式”, 2001信学総大, B-7-206（Mar.2001）

9) http://www.katto.comm.waseda.ac.jp/katto/streaming/

10) W.R.Stevens : “UNIX Network Programming", Prentice Hall (1990)

11) TheTCP-FriendlyWebsite : http://www.psc.edu/networking/tcp_friendly.htm

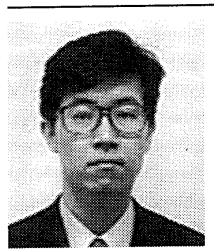

㤎籐 点郎 1987 年, 東京大学工学部電気工学科卒 業. 1992年, 同大学大学院工学系研究科博士課程電子工 学専攻修了. 同年, 日本電気 (株) 入社. 1996年 1997 年, 米国プリンストン大学客員研究員. 1999年, 早稲田 大学理工学部電子・情報通信学科助教授. 主にマルチメ ディア通信, 信号処理の研究に従事. 工学博士. 正会員. 